TADEJ BREZINA, M.Sc. ${ }^{1}$

(Corresponding author)

E-mail: tadej.brezina@tuwien.ac.at

BORNA ABRAMOVIĆ, Ph.D. ${ }^{2}$

E-mail: borna.abramovic@fpz.unizg.hr

DENIS ŠIPUŠ, Ph.D. ${ }^{2}$

E-mail: denis.sipus@fpz.unizg.hr

TAKERU SHIBAYAMA, Ph.D. ${ }^{1}$

E-mail: takeru.shibayama@tuwien.ac.at

${ }^{1}$ Vienna University of Technology,

Institute of Transportation, Research Centre

of Transport Planning and Traffic Engineering

Gußhausstraße 30/230-1, 1040 Vienna, Austria

${ }^{2}$ University of Zagreb,

Faculty of Transport and Traffic Sciences

Department of Railway Transport

Vukelićeva 4, 10000 Zagreb, Croatia
Traffic Infrastructure Original Scientific Paper Submitted: 26 Nov. 2020

Accepted: 7 Apr. 2021

DOI: $10.7307 /$ ptt.v33i5.3753

\title{
BARRIERS TO TRANSNATIONAL PASSENGER RAIL SERVICES IN CROATIA AND BOSNIA AND HERZEGOVINA - A QUALITATIVE PERSPECTIVE
}

\section{ABSTRACT}

Railway infrastructures and services in the countries of former Yugoslavia have been in a downward spiral since the early 1990s. There have been scattered investments to lift services up to appealing levels after the war, but a continuous downward trend persists in all important performance indicators. After war-attributed abandonment, numerous lines lost services permanently, numbers of services dwindled, especially across borders, and service speeds decreased. This research takes Croatia and Bosnia and Herzegovina specifically as survey objects. It aims to identify the barriers in these two countries that withheld passenger rail from a positive development as in other European countries during the same period. For this purpose we carried out 11 interviews with stakeholders in various railway-related institutions. The transcripts are analysed qualitatively with thematic analysis to gain an overview of organisational and institutional barriers for development of railways. This is followed by a cause-effect analysis with Causal Loop Diagramming. The result: ad-hoc decision-making is clearly connected to the insignificance of railways. As immediate measures to counter the downward spiral by means of strategic long term planning, we identify (1) service benchmarking, (2) a clear vision for improvement of service quality, and (3) empowerment of ministries in a long term.

\section{KEYWORDS}

Croatia; Bosnia and Herzegovina; stakeholders; barriers; railway operation; railway deterioration; Causal Loop Diagram.

\section{INTRODUCTION}

South-East Europe in general and former Yugoslavia in particular is a diverse, heterogeneous and complex transnational area, made up of a broad mix of countries. The emergence of new countries in the 1990s and with it the establishment of new national borders has changed the patterns of political, economic, social and cultural relationships in the last three decades, which also had a strong impact on railways [1]. Geographically, former Yugoslavia includes the following countries in alphabetical order: Bosnia and Herzegovina (BiH), Croatia (HR), Northern Macedonia (MK), Montenegro (MNG), Serbia (SRB), and Slovenia (SLO). Historically, the region also underwent name changes, from SouthEast Europe until the time of the Ottoman Empire and after the Second World War, later this area has been called The Balkans [2]. Figure 1 shows a map of the area with railway lines and with Croatia and Bosnia and Herzegovina highlighted. Appendix 1 enumerates key railway statistic data of both countries.

In the $20^{\text {th }}$ century, much of the western part of the region was governed by Yugoslavia, which was a country between the political West and East blocks. Yugoslav president Tito, together with India's first Prime Minister Jawaharlal Nehru and Egypt's second president Gamal Abdel Nasser, founded the Non-Aligned Movement (NAM). In the 


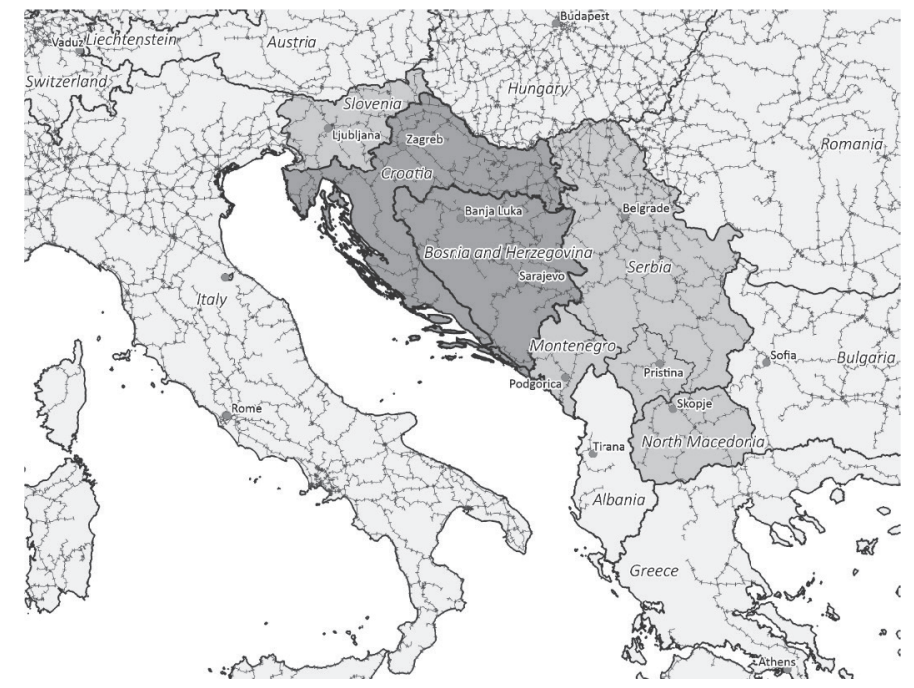

Figure 1-A political overview of former Yugoslavia including railway lines, with Croatia and Bosnia and Herzegovina highlighted

peak period, NAM had 120 countries as its members. The main idea behind NAM was to establish a third direction of political and economic development. As such, Yugoslavia was a country open for the Western and Eastern blocks but also for third parties. The country itself had only one political party, the communist party, making it a derivate between communist and socialist mind-sets $[3,4]$. In this political environment, the transport system held one of the most important roles. Therein the first place was held by the railway system, which was organised in a semi-military manner within the civil society. As Yugoslavia was a federation, the railways were also organised under a leading umbrella institution, the Community of Yugoslav Railways (Zajednica Jugoslovenskih željeznica), uniting the railway companies of the six republics. The railway companies in each republic had their representatives in the umbrella institution. Within this framework, some matters were centralised, such as rule books, tariff system, international relations, and timetables, while other important matters were not centralised. For example education system, healthcare system, procurement of works and of rolling stock are among the ones that were decentralised.

This brought about a situation, for example, that some republics' railway companies bought rolling stock of western provenance while others bought it in the East. A mixture of rolling stock from the West and the East was also possible. Croatia for example bought only western locomotives (e.g. train set from Brissonneau et Lotz JŽ610/HŽ7021) or a licence for production (e.g. electric locomotive from
ASEA JŽ441/HŽ1141). Later their own electric locomotives were developed (Rade Končar JŽ442/ HŽ1142). In Yugoslavia all passenger wagons were produced by Goša (located in Smederevska Palanka, Serbia) and all diesel locomotives by Đuro Đaković (located in Slavonski Brod, Croatia). In passenger services, a network of business trains ("Poslovni vlakovi") was established connecting important centres in Slovenia, Croatia, Bosnia and Herzegovina, and Serbia. The business trains comprised of 1st class coaches and restaurant cars. In addition to the regular train staff (head of the train and conductor), stewardesses served passengers drinks, food, and daily newspapers to their seats. The standard business trains offered a high level of service comparable to the one in Trans Europe Express (TEE) trains in Western Europe. There was also a network of night trains, serving both national and international destinations, providing sleeping wagons and couchette services, $2^{\text {nd }}$ class seating wagons and, if necessary, wagons for transporting cars [5].

At the turn of the 1980s to the 1990 s, democratic changes started in the whole of South-East Europe. Besides the emergence of additional political parties and preparations for first democratic elections, an opening of borders for personal imports (e.g. second hand cars) took place. The private car was considered an important symbol of democracy, triggering the construction of roads for the expected increase in private cars. As a result of the republics drifting apart and increasing ethnic tensions, wars ravaged from 1991 to 1995 in Croatia and from 1992 to 1995 in Bosnia and Herzegovina. Based 
on the Dayton Agreement, Bosnia and Herzegovina was politically divided in two entities: the Federation of Bosnia and Herzegovina (FBiH), and the Republika Srpska (RS). The Federation of Bosnia and Herzegovina itself has a federal structure and consists of 10 autonomous cantons.

The war years accelerated the deterioration of the public transport system in general and especially the railway system. Railway passenger services fell into a very deep hibernation. Passenger numbers dropped steadily and concurrently with a decline in train numbers and capacities, both for lines and vehicles [6]. With a following drop in quality of services, passenger rail transport has been caught in a vicious circle ever since. Politicians, as stakeholders with the most influence in the whole decision-making and implementation process, did not recognise this negative trend in passenger transport and started to change management boards with no clear picture in mind of the goals. Without goals, no concrete actions for trend reversal have been taken [7]. As Croatia is part of the EU, vertical separation has been implemented [8]. HŽ Infrastruktura serves as infrastructure manager and there are two state owned operators, one for passenger transport (HŽ Putnički prijevoz) and one for cargo transport (HŽ Cargo). Bosnia and Herzegovina aims to join the EU, so they are following all EU acquis regarding railway transport [9]. Currently, the system is divided into the infrastructure manager and operator (passenger and cargo together).

In this context, studying mechanisms that lead to deteriorating passenger services and barriers that have been preventing a rejuvenation appears to be vital for the future improvement of both country's railway services.

We carried out two lines of research as a preparatory research setting the ground for a larger research project, and ultimately aiming at reducing the identified barriers within the socio-political system and improving passenger services in long term:

- Long-term (1985-2015) statistical data (key performance indicators) of infrastructure and operations in Croatia and in Bosnia and Herzegovina were collected, as well as timetable data (timings of trains at key stations) for selected lines [6].

- Interviews with eleven railway sector and political science stakeholders in Croatia and Bosnia and Herzegovina were conducted.
Both approaches were carried out under the scope of the project initCOSEERAIL with the aim to prepare foundations for consecutive improvement steps - by means of continuative projects. This paper focuses on the second point and we present results elicited from the analysis of these interviews. It is structured in a way that the relevant literature is delineated in the next section. Materials used and methods applied are displayed in section three. Section four sets out the results which are discussed in section five. Finally, section six draws conclusions based on the findings.

\section{LITERATURE REVIEW}

The qualitative perspective of passenger rail services was discussed in many scientific papers; however, there is only quite a small number of research papers dealing with challenges in passenger railway transport, especially for quality of service. Fraszczyk et al. [10] evaluate current railway systems' performances. They compare various passenger-related parameters of the railway system in a number of selected European countries and draw conclusions on the level of their performance in relation to the European average. The comparison of length of track and capacity of rail vehicles both show a general negative trend. These two variables may be linked together, because when length of track is decreasing, infrastructure managers and train operators may try to reduce the capacity of vehicles as fewer rail routes are available. Abramović et al. [7] carried out a benchmark study of national passenger traffic in Central European countries of Austria, Czech Republic, Slovakia, Hungary, Slovenia, and Croatia. In each country, three characteristic lines were selected with the criteria of distance, travel time, cost, and frequency. They conclude that Austria shows the best results and Croatia the poorest. Results from Austria show that the politicians there have recognised the power of excellent railway passenger transport, and other countries are following in those footsteps, while only Croatia is in the first stage of reorganising railway passenger transport. Abramović [5] also suggests that railway transport is a mirror of the success of national economy. Successful economies also have excellently organised railway sectors, for example Switzerland, Germany, France, and Japan. He emphasises that former Yugoslavia's railway sector needs a new vi- 
sion of development that will put the user into a focus of interest and a new railway paradigm: "We move people and goods, not trains!" [5].

Schopf [11] emphasises user needs as key quality parameters in public transport service provision. Transport services need to be of highest quality to be judged positively by potential users according to the generalised cost notion. Therein, next to the actual ticket price, the total expenditure of travel is considered. The higher the efforts are to use trains, the less attractive it is in comparison to other means of travel. When it comes to user interest, Brezina and Knoflacher [12] conclude that finding harmonised optimum speeds, introducing clock-face timetables and improving access/egress modes are promising strategies for increased customer travel benefits in comparison to other strategies, in particular such as maximisation of mainline travel speeds at the expense of quality on feeder/distributor lines.

Trends in European railways over the last two decades are analysed by Preston [13]. He identified the trends in passenger and freight traffic along with the evolution of the rail network. The increasing role of high-speed rail is particularly highlighted. An attempt is made to determine the extent to which these changes are driven by the reform process or by other factors.

Von Arx et al. [14] study the development of international passenger rail services from 2007 to 2016 for Switzerland. They examine the ways in which international passenger rail services are organised, how they perform and what factors influence their performance. Results are that the quality of service has increased, with more direct connections, increasing frequencies and shortening travel times, and with night trains to southern and eastern Europe still being maintained.

Tomeš and Jandová [15] researched the spatial-organisational features of open access passenger rail services in Central Europe. These open access entries all run on principal domestic railway lines and have caused major increases in train frequencies. New entrants have introduced many service innovations and utilised aggressive price cuts. As a result, they have been able to win substantial market shares from incumbent operators. The impacts of open access entries on the development of railway markets in Central Europe are studied as well.
Effectiveness of regional railway lines is analysed by Dolinayova et al. [16]. In their chapter, the aim is to understand the factors which influence the economic and social efficiency of regional railway transport. They conclude that the problems of regional railway transport are related to the goals of the European transport policy. The fundamental goal of the European transport policy is a competitive and resource-efficient transport system, but the financing schemes focus on large international investment and construction-intense projects, not so much on regional lines and services. Regarding the problems of reducing the dependence on oil, it is a consequential aspect of transport policy to increase rail transport competitiveness. This increase will only occur when rail passenger and freight services are provided in the requested quality and at reasonable prices. It is thus necessary to create an effective system reflecting customer requirements [17].

Stoilova [18] conducted a study of railway passenger transport in the European Union, using a multi-criteria model for rating development. The factors for the classification include the following: (1) social and economic factors, (2) infrastructure factors, (3) factors associated with travel, and (4) technological factors.

This literature review shows a variety of identified problems and barriers in the development of an attractive railway passenger transport - a contemporary line of research in the light of the transport sector's role in climate emissions mitigation. To play a significant role in low emission transport of the future, former Yugoslavia's railways need to overcome today's barriers quickly.

\section{METHODS AND MATERIALS}

As the research design sought to elicit in-depth information on barriers from people in charge, we designed a structured interview incorporating a variety of questions (see Table 1 and Appendix 2) to address representatives of a diverse multi-player system in the two countries at hand (Table 2). The primary interviewees were service operators and infrastructure managers as well as administrators, for the purpose of collecting detailed internal notions. In addition, in order to balance the inside view with an outside perspective, we carried out two interviews with political scientists as well. 
Table 1 -Multidimensional classification of questions (see Appendix 2 for full list)

\begin{tabular}{||l|l||}
\hline By type of organisation: & By type of question: \\
- Ministry of transport & - Communication and cooperation with the "outside" \\
- Passenger operator & - Financial aspects \\
- Freight operator & - Organisational aspects \\
- Infrastructure manager & - Planning, operation, and marketing \\
$-\quad$ Political science & - Strategy and policy \\
- Regulator & - Quality assessment \\
$-\quad$ Notified body & - Unclassified \\
\hline $\begin{array}{l}\text { By time perspective: } \\
-\quad \text { History }\end{array}$ & By the question's content: \\
- Status quo & - S...Status, addressing hard, verifiable facts \\
- Foresight & - O...Opinion, addressing the appraisal and experience of the interviewee \\
\hline
\end{tabular}

Table 2 - Interviewed representatives by territorial entities and by organisations

\begin{tabular}{||c|c|c||}
\hline Territory & Organisation type & Organisation name \\
\hline Croatia & Ministry of transport & Ministry of Sea, Transport and Infrastructure \\
\hline Croatia & Passenger operator & HŽ Passenger Transport LLC \\
\hline Croatia & Freight operator & HŽ Cargo LLC \\
\hline Croatia & Infrastructure manager & HŽ Infrastructure LLC \\
\hline Croatia & Political science & University of Zagreb, Faculty of Political Science \\
\hline Croatia & Regulator & Croatian Regulatory Authority for Network Industries \\
\hline Federation & Ministry of transport & Ministry of Transportation and Communications \\
\hline Republika Srpska & Ministry of transport & Ministry of Transportation and Communications \\
\hline Republika Srpska & Passenger operator & Railways of Republika Srpska \\
\hline Republika Srpska & Freight operator & Railways of Republika Srpska \\
\hline Republika Srpska & Infrastructure manager & University of Banja Luka, Faculty of Political Science \\
\hline Bosnia and Herzegovina & Political science & M \\
\hline
\end{tabular}

Notes: Missing are: Notified Body from Croatia, as well as the passenger, freight, and infrastructure operation branches of ŽFBH. All had been contacted persistently, but no in-person interviews could have been granted to the local project partner. HŽ - Hrvatske željeznice

We translated the questions from English into Croatian and Bosnian, and we contacted representatives of companies/institutions according to Table 2 for an interview. Prior to the interview, each interviewee received the questions in advance, because several questions - especially those classified as status (in contrast to opinion) - require collection of information that may not be immediately available at hand. We recorded the interviews, then transcribed and translated from Croatian/Bosnian into English. English transcripts have been coded and analysed with the qualitative text analysis software "QDA Miner lite" [19], in a similar way to, for example, a research by Moser [20]. To analyse the transcripts, thematic analysis [21] was performed, which allows to identify, analyse, and report patterns (lines of thought) within qualitative data. The elicited, connected ideas are presented in diagrams as line of thought in the following section, and the results illustrate the lines of barrier development.

To understand the cause-effect relations, and thus to enable discussions to identify areas of immediate and future intervention towards the improvement of the railway, we carried out a cause-effect analysis by means of Causal Loop Diagramming (CLD). This is a qualitative method to visualise how different variables in a system are interrelated, and to understand the resulting kind of system behaviour. CLD makes it possible to understand structural forces by visualising cause-effect relationships among different variables in a complex system [e.g. 22, 23]. It consists of four basic elements: (1) the variables (nodes), 
(2) the links (edges) representing connections or relations between variables, (3) the (co-)relation directivity on the link, and the (4) sign of the loop showing what type of behaviour the system will produce. A link marked positive indicates that both variables change in the same direction, e.g. if one starts to increase, the other also starts to increase. A link marked negative indicates that both variables change to the opposite directions, i.e., if one node increases, the other decreases, or vice versa. A closed cycle is defined as a feedback loop, and it is characterised as either a reinforcing or balancing loop. In a reinforcing loop, change in any variables propagates through the cause-effect chains in the loop and reinforces the initial deviation: an increase of one variable in a reinforcing feedback loop will, through the system behaviour, return an increase to the same variable. Similarly, a decrease of one variable will return a decrease to the same variable through the system behaviour in a reinforcing loop - what we know as a vicious circle is also a type of this system behaviour. In a balancing loop, in contrast, change in any variable propagates through the cause-effect chains to return a deviation opposite to the initial one. Reinforcing loops lead to exponential increase or decrease, and balancing loops lead to equilibrium. In transportation, there have been plenty of applications of System Dynamics [24-26].

\section{RESULTS}

All interviewees agreed that the public opinion of the railway in their countries is very poor (Figure 2). During Yugoslav times, the railway was highly used, but since the war this is no longer the case. The lack of investment in infrastructure led to uncompetitive journey times and a general lack of attractive services. Especially the less-used passenger transport service adds to the bad image of the railway in Croatia and Republika Srpska.

"Bad, infrequent, unavailable. Railways are considered as a company that works little and lives on the expense of the country." (Operator, Republika Srpska)

In Republika Srpska, one third of the political representatives are from regions where no railway service exists nearby, which implies difficulties to argue for investments in the railway sector. Furthermore, the political influence on the management of human resources in the railway sector has an unfavourable effect on the public opinion. Figure 2 shows the line of barrier development derived from the aggregated interviews.

The infrastructure suffered during the war and it was never completely rebuilt. Additionally, many of the industrial users of railways were also damaged, which resulted in decrease of business for the railway in the freight sector. Since then, the dearly needed modernisation of infrastructure was not carried out, because of the sparse investment. See Figure 3 for line of barrier development in infrastructure investments.

"...the development of road infrastructure which indebted the state. Today there are insufficient own funds to reconstruct the railway tracks, and there aren't any good projects for ensuring financing from the EU funds. Our tracks are getting worse and worse." (Infrastructure operator, Croatia)

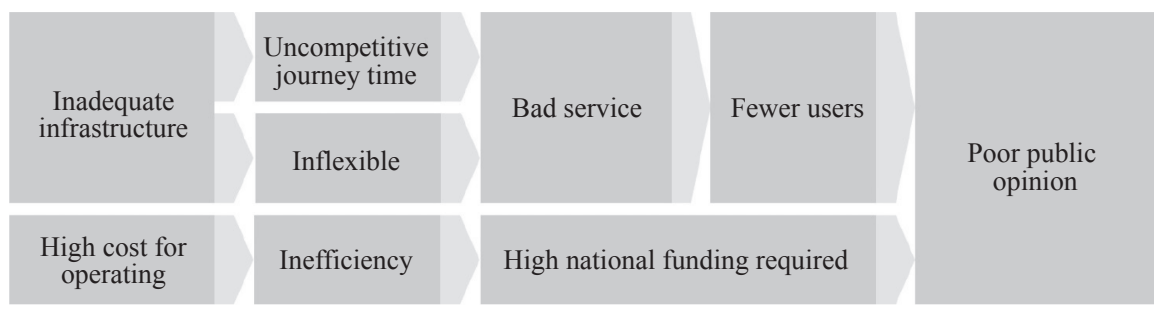

Figure 2 - Line of barrier development associated with politics and public opinion
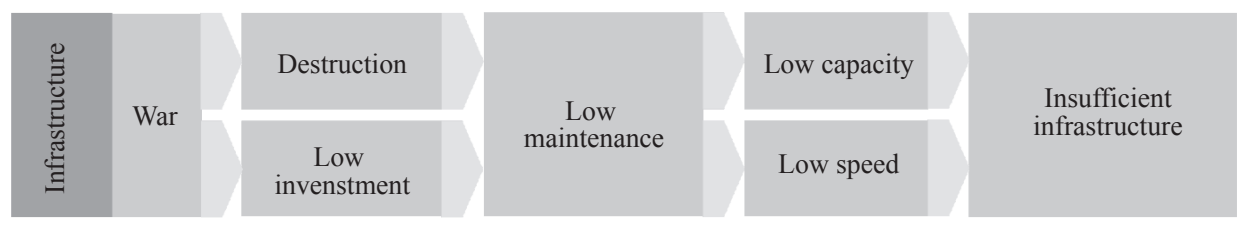

Figure 3 - Line of barrier development associated with quality and funding of the infrastructure 
Another crucial problem is the maintenance of the infrastructure. The quality is getting worse, which leads to low operational speed on the tracks. Furthermore, the existing infrastructure is inadequate by itself: for example, some important corridors only have a single track, which results in problems with capacity.

"The challenge is the railway infrastructure. It's in a terrible condition. If today's commercial cargo train speed goes up to $23 \mathrm{~km} / \mathrm{h}$ then we've got a catastrophic problem. On the other hand, no matter how poor the existing condition is, there's a problem of inadequate infrastructure. If the main transport corridor is from Rijeka to the Hungarian border, and along the entire route there's only a single-track railway, then we've got a serious problem with capacity." (Ministry of transport, Croatia).

These capacity problems lead to an unattractive timetable for passengers. Due to the low speed and insufficient train frequency, passenger services are not competitive. The same applies to the freight transport (see quote above). At the EU level, freight transport has almost the same average commercial speed, and this needs to be tackled in the future so that railways may compete better with road transport. The journey time of road transport will always be more favourable, if the railway infrastructure is not developed and modernised. Without the improvement of infrastructure, foreign operators are also not able to provide a better service, even if they had more options to invest in other production factors, such as rolling stock - see Figure 4.

In terms of rolling stock, in both countries the national funding is primarily used for maintenance of it. At least the wagon cleaning has been improved lately.

"Trains. In our country, most investment goes into maintenance. It's putting the fire out." (Passenger operator, Croatia).

Only the interviewees of HŽ Cargo and the Ministry of Transportation and Communications of $\mathrm{FBiH}$ mentioned investments in the modernisation of the train fleet with positive outcome. At large, the quality of the rolling stock is too low, especially to implement new technologies.
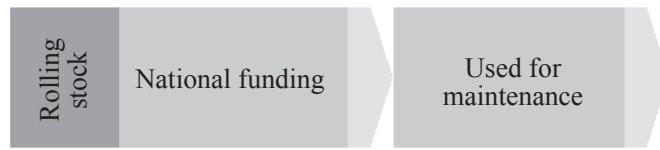

Political interference in human resource management is particularly high in Croatia and in $\mathrm{BiH}$. Especially the influence on the management level is problematic, since the change of the management is very frequent.

"I think the relation politics - railway is stronger than railway - politics. It speaks volumes that in the last 20 years there have been 25 management changes in HŽ Infrastructure." (Regulatory Authority for Network Industries, Croatia)

These constant changes of top managers result in less liability of those in the management position, a weak representation of the railway in general and complicated cooperation. In addition, the human resource management is viewed negatively at all levels - ministry, management, and workers. The political hiring is not only relevant for the management level, but the staff of the railway companies is also influenced. This leads to overemployment in some sectors and to a lack of competence in others, since the factor of staff qualification has been neglected when hiring.

"The railway companies in $\mathrm{BiH}$ are seen as 'bounty' of the political parties that use it to employ their members and for 'buying votes'. This has led to overemployment resulting in a difficult financial situation of the companies. Additionally, the political employment did not focus on competence of the employees, resulting in overstaffing of the financial and administrative sectors of the companies and the neglect of technical, mechanical sectors that are crucial for operations." (Faculty of Political Science, $\mathrm{BiH})$

For example, HŽ Cargo tried to tackle the problem of overemployment by letting go those who were hired last, but this lead to a problematic age structure. Now there are not enough experienced workers in the younger generation to replace experienced older workers who will retire soon. Figure 5 shows the dual lines of barrier development leading to a lack of competence in the railway sector, with the age structure in the railway sector being problematic in both countries. The railway sector in Croatia in 2015 had 8,855 employees, divided into $87.4 \%$ men and $12.6 \%$ women. The age distribution is as follows: $4.3 \%$ are under $30,18.5 \%$ are between 31 and $40,33.0 \%$ are

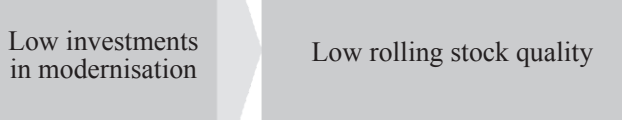

Figure 4 - Line of barrier development associated with quality and funding of rolling stock 

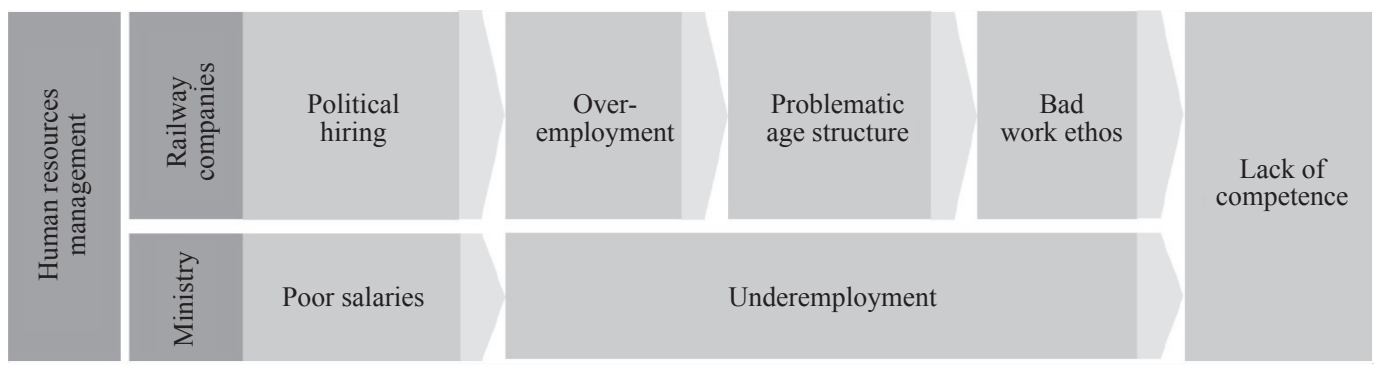

Figure 5 - Lines of barrier development associated with human resources management

between 41 and 50, 42.3\% are between 51 and 60, and $1.9 \%$ are over 60 . The average age of employees is 48 , and the average length of work contracts is 28 years. An additional negative impact of the current age structure is that older employees are less open to adapt to new technologies. Their willingness to gain new skills is low.

"We lack in employee motivation, starting new technologies, implementing novelties without charging for them. The problem with employees is that they expect to be paid extra for each new engagement. Everything that is not a part of the employment contract comes up against a wall. Self-motivation for new ideas and taking courses is boiled down to taking foreign language courses. This is simply not enough for the company and the individual to prosper." (Passenger operator, Croatia)

The low level of motivation is another result of poor human resource management as well as management in general. In Croatia, the equal payment in all sectors is one of the reasons for the motivational problems: for example, a field officer has the same wage as a worker in construction. These factors led to a lack of competence on all levels in the railway sector. Additionally, the high costs of overemployment add to the negative public opinion of the railway sector and its employees. Several interviewees in Croatia mentioned the labour union as another reason for the unresolved human resource issues. The labour unions of the Croatian railway are criticised for not acting constructively in the matter of overemployment. The general accusation is that the labour unions only care about the overall sum of employees, since they charge a percentage of the salary of each worker as their income.

"The unions should generally take care of the workers, but instead, they care only about employing people which is something I've seen for myself. Instead of improving the working conditions for their workers and implementing positive changes, they're dealing with the cadre." (Freight operator, Croatia)
In both countries, the operator states that the labour unions' general influence on decision-making is minimal in both countries. On the contrary, the interviewees at the ministries (Croatia and $\mathrm{FBiH}$ ) and political scientists named them to be very influential because of the high number of employees and their financial revenue.

The transport ministries of both countries are in lack of railway experts and their payment is very low. In addition, in $\mathrm{BiH}$ the ministry is understaffed in general.

"The main problem with human resources is a lack of technical personnel in the companies and ministry (the ministry has 3 people working on rail, water, and combined transport)." (Ministry of transportation, $\mathrm{FBiH}$ )

The ministry in Croatia sees further problems due to the vertical separation of infrastructure and transportation. The internal cooperation as well as the contact with external railway experts leaves room for improvement. The organisational barrier, specifically in Croatia, is a result of the company division and it requires a better overall management and changes in internal organisation of the individual companies.

"If you ask me, a strong railway in the political sense would mean a strong state. Currently, that's not easy to achieve, but we should strive towards achieving it." (Infrastructure operator, Croatia)

This mindset is a potential starting point for possible positive development in the railway services of Croatia and Bosnia and Herzegovina: as such, the interviewees still have some positive mind-sets for future improvement.

\section{ANALYSIS OF CAUSE-EFFECT RELATIONS AND DISCUSSIONS}

As the results from the interviews demonstrate, the problem that we deal with - i.e., the downward trend of the passenger railway in Former Yugoslavia - is not caused by a single reason, but rather a 
result of a socio-political system of the region with complex cause-effect relations embedded in it. In order to identify variables for the CLD, making use of the interview results, we identified the primary problems that lead to insignificance of rail as a means of transport in the region. In some cases, the problem identified in the interview is taken directly, while in other cases several problems are aggregated into one or one problem is subdivided into two. As our research aims to improve passenger services in long term, we focused on the problems relevant to insignificance of railway today. We identified the following problems as the result: these problems are converted in the expression without adjectives that indicates variation within it, which is more suitable as variables of CLD (see Table 3).

As a standard process in the CLD method, we then interconnected these variables by links, and each link is labelled a positive or negative feedback. Then, we identified all reinforcing and balancing feedback loops. The result is shown in Figure 6 .

In this CLD, there are fourteen feedback loops in total. Among them we identified the following nine key feedback loops:

1) Significance of railway - ministry's expertise governance - market orientation - quality of service - significance of railway

2) Significance of railway - ministry's expertise - organisation structure - market orientation quality of service - significance of railway
3) Significance of railway - ministry's expertise - emphasis on new technologies - ad-hoc decision-making - market orientation - quality of service - significance of railway

4) Market orientation - internationalisation perspective - ad-hoc decision-making - market orientation

5) Significance of railway - organisation structure and culture - ad-hoc decision-making - market orientation - quality of service - significance of railway

6) Significance of railway - organisation structure and culture - expert opinions - ad-hoc decision-making - market orientation - quality of service - significance of railway

7) Significance of railway - organisation structure and culture - asset management - ad-hoc decision-making - market orientation - quality of service - significance of railway

8) Significance of railway - organisation structure and culture - asset management - data management - ad-hoc decision-making - market orientation - quality of service - significance of railway

9) Significance of railway - organisation structure and culture - asset management - data management - benchmarking - ad-hoc decision-making - market orientation - quality of service - significance of railway

Table 3 - Problems identified from interviews and translation in CLD variables

\begin{tabular}{|c|c||}
\hline Problem identified from interviews & Variable in CLD \\
\hline \hline Insignificance of railway & Significance of railway \\
\hline $\begin{array}{c}\text { Poor governance and insufficient implementation of } \\
\text { legislation }\end{array}$ & $\begin{array}{c}\text { Governance leading to insufficient implementation of } \\
\text { legislation }\end{array}$ \\
\hline Lack of ministries' expertise & Ministry's expertise \\
\hline Out-of-date organisation structure \& culture & Organisation structure \& culture \\
\hline Lack of market orientation & Market orientation \\
\hline Ad-hock decision-making & Ad-hoc decision-making \\
\hline Inadequate human-resource management & Human resource management \\
\hline Low quality of service & Quality of service \\
\hline Lack of benchmarking & Benchmarking \\
\hline Ignorance of expert opinion & Expert opinions \\
\hline Overemphasis on new technologies & Emphasis on new technologies \\
\hline Poor or missing data management & Data management \\
\hline No internationalisation perspective & Internationalisation perspective \\
\hline Missing or poor asset management & Asset management \\
\hline \hline
\end{tabular}




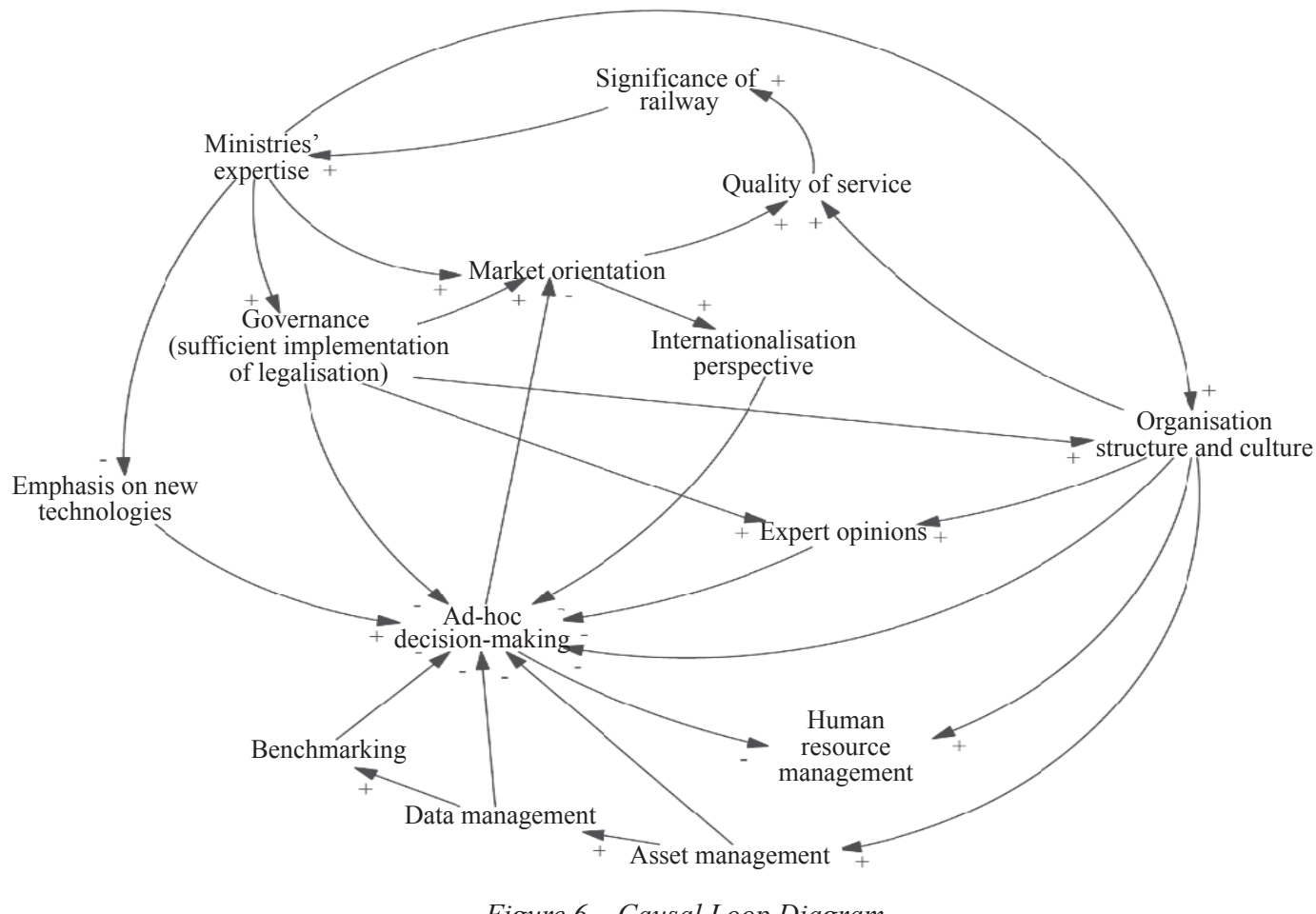

Figure 6 - Causal Loop Diagram

Interestingly, all of these identified feedback loops are reinforcing feedback loops. No balancing loop was identified in our assessment. This is somewhat surprising to us, but this is in line with the initial assumption about the vicious circle. Among these nine loops, we noticed several remarkable variables that contribute to the main problem - insignificance of railway.

Most of the feedback loops go through the cause-effect chain "ad-hoc decision-making market orientation - quality of service" partly or throughout this chain. These three variables are all the matters of railway undertaking and/or infrastructure managers, and thus certainly among the most important aspects towards better significance of the railway in the region. Nowadays, this part of the cause-effect chains works in a way that more ad-hoc decisions are made, leading to less market orientation, and this leads to lower quality of service, leading eventually to insignificance of railway. Turning around these cause-effect chains towards improvement instead of today's deterioration is one of the most important tasks to do.

Looking at the variable "ad-hoc decision-making", we also identified that a number of links end here. Ad-hoc decision-making today itself is understood as a compound effect of various other variables being in a non-optimal situation today. Among many influential variables, (poor) asset management, (lack of) data management, and thus (lack of) benchmarking all leads to ad-hoc decision-making directly or indirectly. Thus, intervention in these variables, in particular benchmarking, will be helpful to turn around the aforementioned cause-effect chain leading to lower quality of service today.

Ministry's expertise is also relevant to many of the feedback loops, through the variable "governance (sufficient implementation of legislation)". Currently, the insufficient expertise of ministries is rather interpreted as a result of low significance of railway in the region, while this influences other important variables influencing the aforementioned cause-effect chain. This is another potential area of intervention towards improvement, while more long-term perspective is needed for this.

"Quality of service" is the variable that is most directly influencing significance of railway. In the current situation, the quality of service is deteriorating as described in the introduction, and this is manifesting the lower significance of railway in the region. This is generally a matter of the railway undertaking and infrastructure manager, but public intervention is also possible as this is also much affected by the feeder modes on road, in particular walking, cycling and road-based public transport. 
Besides these, in comparison with the interview results, several remarkable variables are pointed out. First, human resource management is, in recognition of many interviewees, the cause of many problems (see e.g. Figure 5). In our CLD analysis, this is actually a result of complex cause-effect relations. Second, (out-of-date) organisational structures and cultural influences are repeatedly named in the interviews, while being influenced by the ministry's expertise directly and indirectly.

While ad-hoc decision-making itself is difficult to be systematically influenced, (1) benchmarking and associated data and asset management, (2) provision of visions and methodological guidance for a desired quality of service, and in a long-term (3) the capacity of ministry can help greatly to turn the whole reinforcing feedback loops working towards better direction. We identify these three aspects as the immediate actions to be carried out to overcome the barriers towards improved railway services that serve the region.

\section{CONCLUSIONS}

In the research presented in this paper, in order to understand socio-political barriers to improve passenger railway services in the region, we carried out extensive stakeholder interviews in Croatia and Bosnia and Herzegovina to identify the barriers for improvement of railways. Following this, we carried out a cause-effect analysis using the Causal Loop Diagramming technique. The research results presented here are based on our studies focusing only on the two countries, Croatia and Bosnia and Herzegovina. Nevertheless, because the downward trends of the railways are common in the countries in South-Eastern Europe with a few exceptions, and there are many common and similar aspects in socio-political contexts among the countries in the region, we assume that the results can be, to a large extent, generalised for the region.

The interview results show the following points. The political barrier results in a low level of awareness of the importance of useful strategies and investments in the railway sector in the region. In this context, the quality of the infrastructure and rolling stock, and lack of implementation of new technologies for better productivity are two of the main issues resulting from the insufficient funding, as recognised by many interviewed stakeholders. Human resource management should receive much less political interference, which has a high impact on the sector today.

In both countries regulatory agencies exist. There are two types of regulatory agencies: (1) market regulation and (2) safety and security issues. The competence of regulatory bodies does not have influence on the structure of human resource at the moment. But human resource management in regulatory agencies is also highly connected to political hiring. For efficient and sustainable railway operations - in terms of human resource management - clear recommendations by a third party in terms of human resource strategy need to be drawn.

To enable a firm knowledgebase and exchanges of information throughout the railway sector, it requires strategies and a supportive management for it. The competition with the road transport can be better addressed by legislations and by an implementation of integrated passenger transport.

Through the analysis of cause-effect relations, it became clear that these aspects are interconnected in a complex manner, and several key cause-effect chains play important roles. Furthermore, we identified three areas of primary policy intervention by analysing the feedback loops to improve the passenger railway in the region so that it can again play a significant role as a transport mode.

First, benchmarking, as well as relevant data and asset management, will contribute directly to reduce current practice of ad-hoc decision-making. This is expected to help change the decision-making and planning towards market orientation, away from ad-hoc ways as often observed today.

Second, vision and guidance towards improved quality of services will be needed to serve as a basis for market-oriented decision-making and planning. And third, improvement in expertise and capacity of the ministry will be called for, so that a clear administrative guidance for these two points is given. We do not state that these points are everything that needs to be done in order to improve the railway in the region. Moreover, they are rather conceived as the immediate next step so that further improvement in various domains relevant to railways can take place: For example, legislation and implementation thereof, infrastructure, rolling stock, human resources for policy-making, regulation, management and operation, maintenance, 
train operation, employment of new technologies towards better productivity or user experience, and so on.

\section{ACKNOWLEDGEMENTS}

We would like to thank all interview partners in Croatia and Bosnia and Herzegovina as well as Branko Zlokapa and Slaviša Jelisić, who conducted the interviews in Bosnia and Herzegovina. The research presented in this paper was carried out as part of the project initCOSEERail. The project initCOSEERail was co-financed by the European Union and the City of Vienna under Danube Strategic Project Fund (DSPF), with its grant number "01_ECVII_PA1b". The funding bodies played no particular role in the design of the study and collection, analysis, and interpretation of data and in writing the manuscript.

TADEJ BREZINA, Dipl.-Ing. ${ }^{1}$

(Korrespondierender Autor)

E-mail: tadej.brezina@tuwien.ac.at

BORNA ABRAMOVIĆ, Dipl.-Ing. Dr. ${ }^{2}$

E-mail: borna.abramovic@fpz.unizg.hr

DENIS ŠIPUŠ, Dipl.-Ing. Dr. ${ }^{2}$

E-mail: denis.sipus@fpz.unizg.hr

TAKERU SHIBAYAMA, MEng Dr. techn. ${ }^{1}$

${ }^{1}$ Technische Universität Wien,

Institut für Verkehrswissenschaften,

Forschungsbereich für Verkehrsplanung

und Verkehrstechnik

Gußhausstraße 30/230-1, 1040 Wien, Österreich

2 Universität Zagreb,

Facultät für Transport- und Verkehrswissenschaften

Abteilung für Eisenbahnverkehr

Vukelićeva 4, 10000 Zagreb, Kroatien

\section{BARRIEREN FÜR TRANS-NATIONALE EISENBAHNPERSONENVERKEHRE IN KROATIEN UND BOSNIEN UND HERZEGOVINA - EINE QUALITATIVE PERSPEKTIVE}

\section{ABSTRAKT}

Seit dem Beginn der 1990er befinden sich die Eisenbahnalagen und-angebote der Länder des ehemaligen Jugoslawien in einer Abwärtsspirale. Es gab zwar vereinzelte Investments nach dem Krieg, um die Angebotsqualität auf ein attraktives Niveau zu heben, aber der kontinuierliche Abwärtstrend ist in allen wichtigen Kennziffern ersichtlich. Kriegsbezogene Auflassungen blieben, viele Strecken wurden nicht wieder in Betrieb gesetzt, die Anzahl der Kurse schwand und die Reisegeschwindigkeiten nahmen ab. Kroatien und Bosnien und Herzegovina sind Gegenstand dieser Untersuchung.
Sie zielt darauf ab, die Barrieren in diesen beiden Ländern zu indentifizieren, die einer vergleichbar positiven Entwicklung wie in anderen europäischen Ländern entgegenstehen. $\mathrm{Zu}$ diesem Zweck führten wir Interviews mit 11 Akteuren in unterschiedlichen Institutionen mit Eisenbahnbezug. Die Transkripte wurden mittels Thematischer Analyse qualitativ untersucht, um einen Überblick über organisatorische und institutionelle Barrieren der Eisenbahnentwicklung zu erhalten. Darauffolgt eine Ursache-Wirkung-Analyse mittels Causal-Loop-Diagrammen. Das Resultat: Ad-Hoc-Entscheidungen sind klar mit der Bedeutungslosigkeit der Eisenbahnen verknüpft. Als unmittelbare Maßnahmen schlagen wir vor, um der Abwärtsspirale mit langfristiger strategischer Planung zu begegnen: (1) Benchmarking der Angebote, (2) eine klare Vision für die Angebotsverbesserung und (3) die langfristig zu steigernde Befähigung der Ministerien.

\section{SCHLAGWÖRTER}

Kroatien; Bosnien und Herzegovina; Akteure;

Barrieren; Bahnbetrieb; Bahnverfall; Causal Loop

Diagramme.

\section{REFERENCES}

[1] Howkins TJ. Changing hegemonies and new external pressures: South East European railway networks in transition. Journal of Transport Geography. 2005;13(2): 187-97. DOI: 10.1016/j.jtrangeo.2004.04.011

[2] Todorova MN. Imagining the Balkans. Oxford University Press; 2009.

[3] Bilandžić D. Hrvatska moderna povijest. Zagreb: Golden Marketing; 1999.

[4] Matkovic H. Povijest Jugoslavije, 1918-1991-2003. Zagreb: P.I.P. Pavičić; 2003.

[5] Abramović B. Izazovi željeznice u Hrvatskoj. Obnova, časopis za kulturu, društvo i politiku. 2016;3(6): 93-106.

[6] Brezina $T$, et al. Barriers to trans-national passenger rail services in the Western Balkans - The quantitative background. In: Čokorilo O, editor. Fourth International Conference on Traffic and Transport Engineering (ICTTE 2018); Beograd, Srbija: City Net Scientific Research Center Ltd. Belgrade; 2018. p. 717-24.

[7] Abramović B, Blašković Zavada J, Brnjac N. Benchmarking of national passenger traffic in Central Europe. $22^{\text {nd }}$ International Symposium EURO-ZEL 2014, 3-4 June 2014, Zilina, Slovakia; 2014. p. 1-7.

[8] Finger M, Montero J. Railway regulation: A comparative analysis of a diverging reality. In: Finger M, Montero J, editors. Handbook on Railway Regulation - Concepts and Practice. Edward Elgar; 2020. p. 1-20.

[9] Chavanel C. Towards a new architecture for technical regulation of Europe's railways. In: Finger M, Montero $\mathrm{J}$, editors. Handbook on Railway Regulation - Concepts and Practice. Edward Elgar; 2020. p. 241-56.

[10] Fraszczyk A, Lamb T, Marinov M. Are railways really that bad? An evaluation of rail systems performance in Europe with a focus on passenger rail. Transportation Research Part A: Policy and Practice. 2016;94: 573-91. 
DOI: $10.1016 /$ j.tra.2016.10.018

[11] Schopf JM. Der ÖPNV und seine Kunden - welche Ansprüche stellen die Nutzerinnen und Nutzer? Eisenbahntechnische Rundschau (ETR) mit ETR Austria. 2016;65(6): 50-4.

[12] Brezina T, Knoflacher H. Railway trip speeds and areal coverage. The emperor's new clothes of effectivity? Transport Geography. 2014;39: 121-30. DOI: 10.1016/j. jtrangeo.2014.06.024

[13] Preston J. Trends in European Railways over the last two decades. Built Environment. 2009;35(1): 11-23. DOI: 10.2148/benv.35.1.11

[14] Von Arx W, et al. The development of international passenger rail services from 2007 to 2016: The case of Switzerland. Research in Transportation Economics. 2018;69: 326-36. DOI: 10.1016/j.retrec.2018.07.020

[15] Tomeš Z, Jandová M. Open access passenger rail services in Central Europe. Research in Transportation Economics. 2018;72: 74-81. DOI: 10.1016/j.retrec.2018.10.002

[16] Dolinayova A, Danis J, Cerna L. Regional railways transport - Effectiveness of the regional railway line. In: Marinov M, editor. Sustainable Rail Transport. Lecture Notes in Mobility. Springer International Publishing; 2019. p. 181-200. DOI: 10.1007/978-3-319-78544-8_10

[17] European Commission. Roadmap to a single European transport area - Towards a competitive and resource efficient transport system. White Paper. Luxemburg: EU; 2011.

[18] Stoilova S. Study of railway passenger transport in the European Union. Tehnicki vjesnik. 2018;25(2): 587-95. DOI: $10.17559 / \mathrm{TV}-20160926152630$
[19] Provalis Research. QDA Miner Lite - free qualitative data analysis software. 2018. Available from: https:// provalisresearch.com/products/qualitative-data-analysis-software/freeware/

[20] Moser N. Der Einfluss der Raumstruktur und der sozialräumlichen Umgebung auf urbanes Mobilitätsverhalten im Kontext von Veränderungsprozessen. Diplomarbeit. Technische Universität Wien; 2017.

[21] Braun V, Clarke V. Using thematic analysis in psychology. Qualitative Research in Psychology. 2006;3(2): 77101. DOI: $10.1191 / 1478088706 q p 063 \mathrm{oa}$

[22] Spector JM, Christensen DL, Sioutine AV, McCormack D. Models and simulations for learning in complex domains: Using causal loop diagrams for assessment and evaluation. Computers in Human Behavior. 2001;17(5): 517-45. DOI: 10.1016/S0747-5632(01)00025-5

[23] Kim DH. Guidelines for drawing causal loop diagrams. The Systems Thinker. 1992;3(1):5-6.

[24] Abbas KA, Bell MGH. System dynamics applicability to transportation modeling. Transportation Research Part A: Policy and Practice. 1994;28(5): 373-90. DOI: 10.1016/0965-8564(94)90022-1

[25] Pfaffenbichler P, Emberger G, Shepherd S. A system dynamics approach to land use transport interaction modelling: The strategic model MARS and its application. System Dynamics Review. 2010;26(3): 262-82. DOI: 10.1002/sdr.451

[26] Shepherd SP. A review of system dynamics models applied in transportation. Transportmetrica B: Transport Dynamics. 2014;2(2): 83-105. DOI: $10.1080 / 21680566.2014 .916236$

\section{Appendix 1 - Key statistic data}

\begin{tabular}{||l|c|c||}
\hline & Croatia & Bosnia and Herzegovina \\
\hline \hline Line length [km] & 2,604 & 1,032 \\
\hline Single track line length [km] & 2,350 & 032 \\
\hline Double track line length [km] & 254 & 770 \\
\hline Electrified line length [km] & 970 & 93 \\
\hline Diesel locomotives [number] & 156 & 75 \\
\hline Electric locomotives [number] & 107 & 0 \\
\hline DMU [number] & 45 & 8 \\
\hline EMU [number] & 39 & 33 \\
\hline Passenger kilometres [106 pkm] & 915 & 1,282 \\
\hline Freight kilometres [106 ntkm] & 2,184 & 6,702 \\
\hline Employees [number] & 8,855 & 0 \\
\hline
\end{tabular}




\section{Appendix 2 - Questions classified by institutions and question types}

The questions are categorised into the ones about the past ("Historical questions"), current status ("Status quo questions"), and about future perspectives ("Foresight questions"). Interviewees are categorised into four groups, and we implemented sets of questions for each interviewee group so that interviewees have to answer only relevant questions. Each question is labelled as an opinion of the interviewee (O) or as a status recognised by them (S). The table below shows all of the questions, and the designated interviewee groups as well as the question type of each of them.

\begin{tabular}{|c|c|c|c|c|c|}
\hline \multicolumn{4}{|c|}{ Interviewee } & \multirow[b]{2}{*}{ 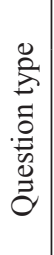 } & \multirow[b]{2}{*}{ Question } \\
\hline 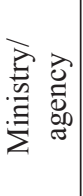 & 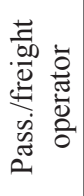 & 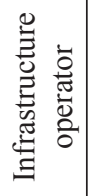 & 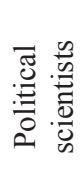 & & \\
\hline \multicolumn{6}{|c|}{ Historical questions } \\
\hline$\sqrt{ }$ & & & $\sqrt{ }$ & $\mathrm{O}$ & $\begin{array}{l}\text { What are the political dynamics that have led to the status quo in the railway sector in gener- } \\
\text { al? }\end{array}$ \\
\hline$\sqrt{ }$ & $\sqrt{ }$ & $\sqrt{ }$ & & $\mathrm{O}$ & $\begin{array}{l}\text { What are the political dynamics that lead to the status quo of your organisation (organisation/ } \\
\text { funding/policies/...)? }\end{array}$ \\
\hline$\sqrt{ }$ & $\sqrt{ }$ & $\sqrt{ }$ & & $\mathrm{S}$ & Does your organisation do historical trend analysis? \\
\hline$\sqrt{ }$ & $\sqrt{ }$ & $\sqrt{ }$ & & $\mathrm{S}$ & $\begin{array}{l}\text { Which indicators are used by your organisation? (Please illustrate the historic development } \\
\text { since ca. 1985.) }\end{array}$ \\
\hline$\sqrt{ }$ & $\sqrt{ }$ & $\sqrt{ }$ & $\sqrt{ }$ & $\mathrm{O}$ & Which organisational milestones illustrate the historic development since ca. $1985 ?$ \\
\hline$\sqrt{ }$ & $\sqrt{ }$ & $\sqrt{ }$ & & $\mathrm{O}$ & $\begin{array}{l}\text { In your opinion, what were the } 3 \text { most efficient investments in the railway sector in the last ten } \\
\text { years (infrastructure/rolling stock/energy supply/signalling and operation)? }\end{array}$ \\
\hline$\sqrt{ }$ & $\sqrt{ }$ & $\sqrt{ }$ & & $\mathrm{O}$ & $\begin{array}{l}\text { In your opinion, what were the } 3 \text { most inefficient investments in the railway sector in the last } \\
\text { ten years (infrastructure/rolling stock/energy supply/signalling and operation)? }\end{array}$ \\
\hline$\sqrt{ }$ & $\sqrt{ }$ & $\sqrt{ }$ & & $\mathrm{O}$ & $\begin{array}{l}\text { According to official statistical data, the railway traffic has been decreasing for the last ten } \\
\text { years. Do you think that this trend will continue? }\end{array}$ \\
\hline \multicolumn{6}{|c|}{ Status quo questions } \\
\hline & $\sqrt{ }$ & $\sqrt{ }$ & & $\mathrm{S}$ & Is there a cooperation with national \& international service providing/enabling organisations? \\
\hline$\sqrt{ }$ & $\sqrt{ }$ & $\sqrt{ }$ & $\sqrt{ }$ & $\mathrm{O}$ & $\begin{array}{l}\text { Which mechanisms are responsible for coming to the status quo as it is (e.g. organisation/ } \\
\text { funding/policies/...)? }\end{array}$ \\
\hline$\sqrt{ }$ & $\sqrt{ }$ & $\sqrt{ }$ & & $\mathrm{O}$ & Which milestones in law implementation were crucial for changes in your organisation? \\
\hline$\sqrt{ }$ & $\sqrt{ }$ & $\sqrt{ }$ & & $\mathrm{O}$ & Which organisations/institutions do you consider the most crucial for your work? \\
\hline$\sqrt{ }$ & $\sqrt{ }$ & $\sqrt{ }$ & & $\mathrm{S}$ & How do information flows between these organisations and yours work? \\
\hline$\sqrt{ }$ & $\sqrt{ }$ & $\sqrt{ }$ & & $\mathrm{S}$ & How do financial flows between these organisations and yours work? \\
\hline$\sqrt{ }$ & $\sqrt{ }$ & $\sqrt{ }$ & & S & $\begin{array}{l}\text { Are the subsidies for service/infra operation being taken care of when budgeting (before ser- } \\
\text { vice provision) or when accounting (after service provision)? }\end{array}$ \\
\hline \multirow[t]{2}{*}{$\sqrt{ }$} & $\sqrt{ }$ & $\sqrt{ }$ & & $\mathrm{S}$ & How and at which time is your organisation involved in designing/improving timetables? \\
\hline & $\sqrt{ }$ & $\sqrt{ }$ & & $\mathrm{S}$ & What are the marketing channels that your organisation uses for railway services? \\
\hline$\sqrt{ }$ & $\sqrt{ }$ & $\sqrt{ }$ & & $\mathrm{S}$ & $\begin{array}{l}\text { Does your organisation conduct performance monitoring periodically in terms of economics, } \\
\text { rolling stock, passengers/goods transported...? If yes, what does the monitoring tell? }\end{array}$ \\
\hline$\sqrt{ }$ & $\sqrt{ }$ & $\sqrt{ }$ & $\sqrt{ }$ & $\mathrm{O}$ & $\begin{array}{l}\text { What is the main barrier for the acceptance of new technology (e.g. digitalisation/automation/ } \\
\text { vending machines/web-ticketing/ERTMS/ETCS/...)? }\end{array}$ \\
\hline$\sqrt{ }$ & $\sqrt{ }$ & $\sqrt{ }$ & & $\mathrm{S}$ & $\begin{array}{l}\text { What are your concrete measures for greening of transport in your organisation (e.g. electrifi- } \\
\text { cation/eco-friendly train operation/EMAS/CO2 emissions reduction/emissions reduction/...)? }\end{array}$ \\
\hline$\sqrt{ }$ & $\sqrt{ }$ & $\sqrt{ }$ & & $\mathrm{S}$ & What is the status of implementation of an integrated passenger/intermodal cargo system? \\
\hline$\sqrt{ }$ & $\sqrt{ }$ & $\sqrt{ }$ & $\sqrt{ }$ & $\mathrm{O}$ & What is the current problem with human resources (age structure)? \\
\hline$\sqrt{ }$ & $\sqrt{ }$ & $\sqrt{ }$ & $\sqrt{ }$ & $\mathrm{O}$ & What is the role of the Workers Unions in the railway sector? \\
\hline
\end{tabular}


Brezina T, et al. Barriers to Transnational Passenger Rail Services in Croatia and Bosnia and Herzegovina - A Qualitative...

\begin{tabular}{|c|c|c|c|c|c|}
\hline$\sqrt{ }$ & $\sqrt{ }$ & $\sqrt{ }$ & & $\mathrm{O}$ & Is there's something to be learned from railways in other countries? \\
\hline$\sqrt{ }$ & $\sqrt{ }$ & $\sqrt{ }$ & $\sqrt{ }$ & $\mathrm{O}$ & Is there's something to be learned from other transport sectors? \\
\hline$\sqrt{ }$ & $\sqrt{ }$ & $\sqrt{ }$ & $\sqrt{ }$ & $\mathrm{O}$ & What is the role of the railway sector in the political landscape? \\
\hline$\sqrt{ }$ & $\sqrt{ }$ & $\sqrt{ }$ & $\sqrt{ }$ & $\mathrm{O}$ & What is the general image of the railway system among the public in your territorial entity? \\
\hline$\sqrt{ }$ & $\sqrt{ }$ & $\sqrt{ }$ & & $\mathrm{O}$ & $\begin{array}{l}\text { Do you know of some examples of progressive/best practice solutions of the past from your } \\
\text { organisation? }\end{array}$ \\
\hline \multirow[t]{2}{*}{$\sqrt{ }$} & $\sqrt{ }$ & $\sqrt{ }$ & $\sqrt{ }$ & $\mathrm{O}$ & Why are, in your opinion, investments in roads higher than in railways? \\
\hline & $\sqrt{ }$ & $\sqrt{ }$ & & $\mathrm{O}$ & $\begin{array}{l}\text { What do you think is the public perception of your organisation in your territorial entity (in } \\
\text { terms of railways)? }\end{array}$ \\
\hline$\sqrt{ }$ & $\sqrt{ }$ & $\sqrt{ }$ & & $\mathrm{O}$ & $\begin{array}{l}\text { What do you think other organisations in your territorial entity think of your organisation (in } \\
\text { terms of railways)? }\end{array}$ \\
\hline$\sqrt{ }$ & $\sqrt{ }$ & $\sqrt{ }$ & & $\mathrm{O}$ & What do you think about other organisations in your territorial entity (in terms of railways)? \\
\hline$\sqrt{ }$ & $\sqrt{ }$ & $\sqrt{ }$ & & $\mathrm{O}$ & What do you consider to be the greatest strength and weakness of your organisation? \\
\hline \multicolumn{6}{|c|}{ Foresight questions } \\
\hline$\sqrt{ }$ & $\sqrt{ }$ & $\sqrt{ }$ & & $\mathrm{S}$ & Do you have a strategic document/plan? \\
\hline$\sqrt{ }$ & $\sqrt{ }$ & $\sqrt{ }$ & & $\mathrm{S}$ & Which strategies (EU) are embedded in your institution's strategy? \\
\hline$\sqrt{ }$ & $\sqrt{ }$ & $\sqrt{ }$ & & $\mathrm{O}$ & What is your appraisal of likely improvement scenarios (how, who, when)? \\
\hline$\sqrt{ }$ & $\sqrt{ }$ & $\sqrt{ }$ & $\sqrt{ }$ & $\mathrm{S}$ & $\begin{array}{l}\text { Do investment programmes exist in your territorial/organisational entity for infrastructure/ } \\
\text { rolling stock/services/energy supply/signalling and operation? }\end{array}$ \\
\hline$\sqrt{ }$ & $\sqrt{ }$ & $\sqrt{ }$ & & $\mathrm{O}$ & What are the three most urgent priorities? \\
\hline$\sqrt{ }$ & $\sqrt{ }$ & $\sqrt{ }$ & & $\mathrm{O}$ & What are the three most important (long term period) priorities? \\
\hline$\sqrt{ }$ & $\sqrt{ }$ & $\sqrt{ }$ & $\sqrt{ }$ & $\mathrm{O}$ & What are the three most challenging barriers? \\
\hline$\sqrt{ }$ & $\sqrt{ }$ & $\sqrt{ }$ & $\sqrt{ }$ & $\mathrm{O}$ & What are the drivers to overcome those 3 challenging barriers? \\
\hline$\sqrt{ }$ & $\sqrt{ }$ & $\sqrt{ }$ & & $\mathrm{O}$ & $\begin{array}{l}\text { What kind of trend do you expect for (A) commuter, (B) national, (C) international services } \\
\text { for the next } 5 \text { years to come? }\end{array}$ \\
\hline$\sqrt{ }$ & $\sqrt{ }$ & $\sqrt{ }$ & & $\mathrm{O}$ & Whom do you consider to be the biggest competitor against railways (bus/car/truck)? \\
\hline$\sqrt{ }$ & $\sqrt{ }$ & $\sqrt{ }$ & & $\mathrm{O}$ & Do you have a plan to address this competition situation? \\
\hline$\sqrt{ }$ & $\sqrt{ }$ & $\sqrt{ }$ & $\sqrt{ }$ & $\mathrm{O}$ & Is there a need for a common interest group, spanning the whole railway sector? \\
\hline$\sqrt{ }$ & $\sqrt{ }$ & $\sqrt{ }$ & $\sqrt{ }$ & $\mathrm{O}$ & $\begin{array}{l}\text { What do you consider to be the most realistic opportunity and threat to improvement of the } \\
\text { railway sector? }\end{array}$ \\
\hline
\end{tabular}

O-Opinion, S-Status 